\title{
Supplier Selection through Application of DEA
}

\author{
Manjari Sahai ${ }^{a}$, Prince Agarwal ${ }^{\mathrm{b}}$, Vaibhav Mishra ${ }^{\mathrm{c}}$, Monark Bag $^{\mathrm{d}, *}$, Vrijendra Singh $^{\mathrm{c}}$ \\ ${ }^{a}$ Denave India Pvt Ltd, Noida, Uttar Pradesh -201301, India \\ ${ }^{b}$ HCL Technologies, Noida, Uttar Pradesh-201301, India \\ ${ }^{c}$ Indian Institute of Information Technology Allahabad, Uttar Pradesh -211012, India \\ ${ }^{d}$ Institute of Rural Management Anand, Gujarat-388001, India
}

\begin{abstract}
In the increasing competition it has become important in business world to understand the different aspects of production and purchasing to understand the need for desired material in the organization. The managers have an important responsibility of selecting a good supplier by evaluating them on different parameters which is directly or indirectly associated with their overall performance. For decision making based on multiple criteria evaluation many methods of Multi-Criteria Decision Making (MCDM) is used by firms. Data Envelopment Analysis (DEA) is prominently used by firms nowadays. In this paper, analysis of DEA is done by measuring supplier performance of two firms: multi-national telecommunication corporation and a manufacturing firm. The firm uses the methodology according to their requirement and criteria for evaluating their suppliers and find best among them.
\end{abstract}

Index Terms: Supplier efficiency, Data Envelopment Analysis (DEA), multi criteria decision making, Supplier evaluation.

(C) 2014 Published by MECS Publisher. Selection and/or peer review under responsibility of the Research Association of Modern Education and Computer Science.

\section{Introduction}

In current scenario production cost is affected by supplier linkages to a great extent. Supplier evaluation and selection methods were earlier based on quoted price which neglected significant direct and indirect costs associated with important operational factors like quality, use and service elements of parts and materials being purchased and delivery, etc. Thus, lowest bidder was selected irrespective of the service which the supplier will provide in terms of other factors. Also, it was waste of time and resources which hampered firm's overall performance. Now, it has become pivotal for all business to evaluate its vendors according to

* Corresponding Author: Monark Bag

E-mail address: monarkbag@gmail.com 
some method to get desired service that can give business cutting edge over other products in the market. The decision methods used for evaluating vendors must be selected as per the requirement of the business. The parameters like cost, quality, performance, etc. should be considered as per firm's requirement. The company has to select suppliers strategically to withstand the market pressure and its impact on different areas of a firm. Selection involves evaluation of different suppliers on different criteria. Thus, firms have to decide among the different MCDM methods of selecting supplier depending upon the working style and top priorities of the firm. Previous researchers have proposed various MCDM techniques for easy and effective way to tackle with vendor selection problem which includes techniques Analytical Hierarchy process (AHP), Data Envelopment Analysis (DEA), etc. Among all the methods used DEA has been extensively used for supplier evaluation and selection. The main aim is to study the application of DEA technique depending on firm's strategy to do business. This paper will help in further research in DEA and in understanding different aspects of this method in selection of suppliers.

\section{Literature Review}

Supplier evaluation and selection is an important criterion in both large and small firms for development of companies. Data Envelopment Analysis or DEA is widely used approach for supplier evaluation and selection for individual products. The decision making units were analyzed and relative efficiencies were calculated based on weighted sum of costs as input and weighted sum of deliverables as outputs (Charnes, 1978). Identify the major technical inefficiencies in inputs or outputs to give best possible results (Banker, 1984). Further calculating inefficiencies by exogenously fixing some of the inputs or outputs which cannot be controlled (Banker, 1985). Detailed evaluation of inputs and outputs and issues involved in the practice of DEA (Boussofiane, 1991).Weber (1996) proposed a model of supplier evaluation on the basis of multiple criteria and setting a benchmark for evaluation. The main factors discussed were reduction in cost, good quality and efficient delivery. Depending on the changing market scenario Braglia and Petroni (2000) conducted a survey with 89 manufacturing firms in Brescia (Europe) for proper formulation of sourcing strategies and applied DEA to measure the related performance of various suppliers based upon the article of Baker and Talluri (1997). Liu et al. (2000) came up with the simplified DEA model to evaluate the supplier performance with 3 inputs (Price Index, Delivery Performance and Distance Factor) and 2 output criteria (Supply Variety and Quality). Forker and Mendez (2001) proposed the application of DEA to measure comparative efficiency of suppliers. Comparative Efficiency was calculated as a ratio of single input to multiple outputs. Similar to Braglia and Petroni (2000), focused on evaluation of supplier performance depending on cross efficiencies. Narasimhan et al. (2001) focused on supplier evaluation specifically for a Multi-national corporation in telecommunication industry. Eleven factors were considered in which six inputs denoted supplier's capability and rest five outputs symbolized supplier's performance. Talluri and Baker (2002) used three phase approach for logistic distribution network design in which 2 input factors and 4 output factors were used to evaluate potential stakeholders (suppliers, manufacturers, distributors, retailers). The optimal supplier was selected for different locations and products as per the requirements.

Using the same evaluating factors proposed by Talluri and Baker (2002), DEA was used to measure the supplier performance by Talluri and Sarkis (2002) and showed that the model works. Talluri and Narasimhan (2004) used DEA for effective sourcing and proposed a model using cross efficiencies and statistical methods in clustering the supply base. Garfamy (2006) applied DEA for supplier performance evaluation on the basis of Total Cost of Ownership (TCO) and tried to simulate data of a hypothetical firm with the strategic aim of being able to reduce TCO with identification of benchmarks. Ross et al. (2006) identified DEA method to be the core of an analytical framework - namely Action Research (AR). The proposed methodology fused both buyer and supplier performance attributes and was found capable of delivering measurable and actionable outputs. There were two main goals: first, to set up a mutual and reciprocal understanding of the opposite needs of the buyers and suppliers in the relationship dyad. Second was to set an approach for performance evaluation in the relationship. Saen (2006) developed a model based on DEA method to select technology 
suppliers with respect to three factors. Seydel (2006) used DEA with a different approach with no input selected in the model. The article used seven point scales for ranking of the qualitative aspects of the suppliers. Further the article illustrates the benefit of DEA as it required less effort than Simple Multi-Attribute Rating Technique (SMART). Talluri et al. (2006) proposed a chance-constrained DEA approach to evaluate supplier performance taking into consideration the stochastic performance measures. This study takes into account the need for variability in vendor attributes in selecting and evaluating supplier. The input criteria considered was Price, while outputs were quality and delivery. The usefulness of the model was shown by comparing it with the deterministic DEA. Wu et al. (2007) discussed an augmented DEA approach for selection of suppliers. The model handled imprecise data (rank the efficient suppliers) and covered the discrimination among them (discriminate efficient suppliers from relatively poor performers). To allow interested parties in supplier selection and evaluation, a web-based system was designed by researchers. Kao (2010) proposed common weight DEA for ranking alternatives and focused on measurement of the relative distance from the ideal (best alternative as per the criteria) and anti-ideal alternative (worst alternative). If in case two options have the identical distance from the ideal alternative, then the one with higher distance from the anti-ideal would be most suitable option of the two and hence ranked higher. Mondal and Chakraborty (2010) proposed the idea of selection of flexible manufacturing system in an organization using DEA. Initially, the alternatives were selected based on best criterion as per the DEA model of Charnes, Cooper and Rhodes (CCR) and then the shortlisted alternatives were rated on the basis of the weighted efficiency ranking method of MCDM theory.

\section{The DEA Model}

DEA is a non-parametric methodology of efficiency calculation of decision making units (DMUs) which considers multiple inputs and outputs. This approach does not depend on specifications like production function, weights, etc of different selected inputs and outputs. Using DEA, assessment of comparative efficiencies of supplier, one of the decision making unit, is done in this paper. Different inputs used for measuring performance and analyzing decision making unit (DMU), considering a supplier, to get desired output depending on industry is shown in Fig. 1.

\subsection{DEA Model for measuring Supplier Efficiency}

In this approach we will utilize Pareto-Koopmans efficiency measure of suppliers proposed by Charnes et al (1978). In this Farrell's measure is used as a base for measurement of efficiency. Efficiency of decision making unit (DMU), here it is supplier, can be determined through absence of slack. Pareto- Koopmans relation with slack and efficiency of DMU is shown in Table 1.

Table 1 is utilized in evaluating supplier through the formula: minimize $\mathrm{X}$,

$$
\text { where: } \quad X=\theta_{o}-\xi\left(\sum_{i=1}^{m} \mathbf{S}_{i}^{-}\right)
$$

$\theta_{o}$ is Farrell's efficiency measure for vendor $o$;

$S_{i}^{-}$are input criteria slack variables;

$\xi$ is an infinitesimally small number;

$m$ is the number of criteria;

Vendor is efficient as compared other vendors if in the above equation Farrell efficiency value is 1.0, with 0.0 slack values. If Farrell efficiency value is less than 1.0 or slack values are greater than 0.0 , then vendor is inefficient and its performance is worse as compared others as shown in table above. 
Also general formula of calculation of efficiency is also used.

Efficiency $=\frac{\text { Weighted sum of Output }}{\text { Weighted sum of Inputs }}$

INPUT

DMU

OUTPUT

Quality

Delivery

Performance History

Price

Technical Capability

Financial Position

Reputation and Position In Industry

Communication System

Procedural Compliance

Geographical Location

Repair Service

Operating Controls

Attitude

Impressions

Packaging Ability

Fig. 1. DEA Model for Supplier selection

Table 1. Pareto-Koopmans Efficiency Relationship with DEA

\begin{tabular}{|l|l|l|}
\hline Farrell Efficiency Value & Slack Value & DEA Efficiency Status \\
\hline 1.0 & 0.0 & Efficient \\
\hline 1.0 & $>0.0$ & Inefficient \\
\hline$<1.0$ & 0.0 & Inefficient \\
\hline$<1.0$ & $>0.0$ & Inefficient \\
\hline
\end{tabular}

\section{Illustrative Example}

\section{Example 1:}

Considering data of a multi-national telecommunications company from Talluri and Narashimhan (2004) in which twenty three suppliers were evaluated on the basis of six input parameters: quality management practices and systems(QMP), process/manufacturing capability (PMC), management of the firm (MGT), documentation and self-audit (SA), design and development capabilities (DD), cost reduction capability (CR) and five output parameters: price, delivery, quality, cost reduction performance (CRP), other. The designing 
of questionnaire was in such a way to evaluate the output of suppliers on the composite score of 0 to 1 . The calculated efficiency score of the suppliers from the data of the firm's survey in different category is shown in Table 2.

Taking into account the efficiency score, in terms of the supplier performance vendor 15 is most suitable for the firm and supplier 18 is worst. In this evaluation, according to efficiency vendors can be evaluated and selected without giving any information for their improvement.

Table 2. Efficiency calculation on the basis of different input and output parameters

\begin{tabular}{|c|c|c|c|c|c|c|c|c|c|c|c|c|}
\hline Vendor & QMP & SA & PMC & MGT & DD & CR & Quality & Price & Delivery & CRP & Other & $\begin{array}{l}\text { Efficiency } \\
\text { Score }\end{array}$ \\
\hline 1 & 662 & 0.9742 & 0385 & 0808 & 1417 & 0.7839 & 6211 & 892 & 1284 & 2107 & 6359 & 0.5828 \\
\hline 2 & 7054 & .0438 & 0.75 & 0.8782 & 0 & 0.875 & 6932 & 0.892 & 55 & 0 & 99 & 82 \\
\hline 3 & 5611 & .8947 & 7789 & 0.7205 & 0.8372 & 0.7404 & 1.0205 & 0.434 & 1.542 & 0 & 1.2719 & 0.9417 \\
\hline 4 & 1272 & 1.0438 & 0.952 & 0.9607 & 0.9661 & 1.1402 & 1.6639 & 1.133 & 1.542 & 1.2107 & 1.8019 & 1.1877 \\
\hline 5 & 272 & .0438 & .1251 & 1.0808 & 1.256 & 1.2115 & 0.9983 & 1.35 & 1.1565 & 1.2107 & 0.954 & 0.8284 \\
\hline 6 & 0.9877 & 1.0438 & 0.9376 & 1.0808 & 1.0466 & 0.9422 & 1.0426 & 1.326 & 1.799 & 2.4214 & 1.2719 & 1.3018 \\
\hline 7 & 0.8051 & 0.8351 & 1.0385 & 0.9607 & 1.256 & 1.0768 & 1.2201 & 1.206 & 0.771 & 2.4214 & 1.2719 & 1.1537 \\
\hline 8 & 1.1809 & 1.0438 & 1.1251 & 1.0208 & 1.0627 & 1.0096 & 0.8429 & 1.133 & 0.6424 & 1.2107 & 0.8479 & 0.726 \\
\hline 9 & 1.2346 & 1.0438 & 1.1251 & 1.0808 & 1.256 & 1.1442 & 0.6433 & 0.892 & 0.3855 & 0 & 0.5299 & 0.356 \\
\hline 10 & 0.5904 & 1.0438 & 0.6058 & 0.7629 & 0.5796 & 0.4038 & 1.4419 & 0.434 & 1.4135 & 0 & 1.2719 & 1.1443 \\
\hline 11 & 0.8642 & 0.8118 & 0.8182 & 0.9536 & 0.9661 & 0.8076 & 0.4215 & 0.892 & 1.0279 & 0 & 0.8479 & 0.6108 \\
\hline 12 & 0.6441 & 0.8351 & 1.0227 & 1.0208 & 0.9661 & 1.0768 & 1.0205 & 1.326 & 0.771 & 1.2107 & 0.7418 & 0.911 \\
\hline 13 & 1.2346 & 1.0438 & 1.1251 & 1.0808 & 1.256 & 1.2115 & 0.5546 & 1.109 & 1.0279 & 1.2107 & 1.166 & 0.7291 \\
\hline 14 & 1.0662 & 1.0438 & 1.1251 & 1.0808 & 1.1593 & 1.2115 & 0.8208 & 0.892 & 0.8994 & 1.2107 & 0.8479 & 0.6986 \\
\hline 15 & 1.01 & 1.0438 & 0.8654 & 1.0208 & 0.7322 & 0.6815 & 1.2423 & 1.567 & 1.4135 & 2.4214 & 1.2719 & 1.4787 \\
\hline 16 & 0.8978 & 0.9742 & 1.0385 & 1.0208 & 0.942 & 0.8076 & 1.0205 & 0.892 & 0.3855 & 0 & 0.424 & 0.4792 \\
\hline 17 & 1.1272 & 0.9742 & 1.0385 & 1.0208 & 1.256 & 1.0768 & 1.0205 & 0.868 & 0.771 & 0 & 0.5299 & 0.4912 \\
\hline 18 & 1.1809 & 1.0438 & 1.1251 & 1.0808 & 1.256 & 1.2115 & 1.2201 & 0.241 & 0 & 0 & 0.424 & 0.2733 \\
\hline 19 & 1.0735 & 1.0438 & 1.1251 & 0.9007 & 1.1593 & 0.9422 & 1.1647 & 0.892 & 1.4135 & 1.2107 & 1.0599 & 0.9194 \\
\hline 20 & 1.0735 & 1.0438 & 1.1251 & 1.0808 & 0.6762 & 1.1442 & 0.8429 & 1.055 & 1.4135 & 1.2107 & 1.4839 & 0.9776 \\
\hline 21 & 1.2346 & 1.0438 & 1.1251 & 1.0133 & 1.256 & 1.2115 & 0.7764 & 0.892 & 1.0279 & 0 & 0.954 & 0.5303 \\
\hline 22 & 1.2346 & 1.0438 & 0.952 & 1.0808 & 1.0466 & 1.2115 & 1.4642 & 1.326 & 1.799 & 2.4214 & 1.4839 & 1.2931 \\
\hline 23 & 1.0735 & 1.0438 & 1.0385 & 1.0172 & 0.8695 & 1.0768 & 1.2423 & 1.35 & 1.2849 & 2.4214 & 1.59 & 1.2892 \\
\hline
\end{tabular}

\section{Example 2:}

In terms of sensitivity evaluation, an example considering Farrell's efficiency is studied.

Consider an example of a manufacturing firm from Weber et al (1996) in which six suppliers competed for an item being purchased at test plant. Since company was operating in JIT environment so three criteria: price, quality and delivery were taken for measurement of supplier efficiency. The measurement of different criteria was done independently. Price was measured by minimizing total price of purchase, delivery criterion by calculating percentage of ordered units that were late and quality criterion by percentage of units being shipped and were discarded. 
Out of material demand of 10,790,000 units with annual cost of $\$ 3.5$ million approximately the allocation to individual vendor is shown in Table 3.

Table 3. Data of resource allocation to individual vendors

\begin{tabular}{|l|l|l|l|l|l|l|}
\hline Vendors & V1 & V2 & V3 & V4 & V5 & V6 \\
\hline Price/unit & 0.1958 & 0.1881 & 0.2204 & 0.2081 & 0.2118 & 0.2096 \\
\hline \% Late deliveries & 5.0 & 7.0 & 0.0 & 0.0 & 3.0 & 4.0 \\
\hline \% Rejects allocation & 1.2 & 0.8 & 0.0 & 2.1 & 2.3 & 1.2 \\
\hline $\begin{array}{l}\text { Business } \\
\text { (units) }\end{array}$ & $2.0 \mathrm{~m}$ & $200 \mathrm{k}$ & $1.09 \mathrm{~m}$ & $3.0 \mathrm{~m}$ & $2.0 \mathrm{~m}$ & $2.5 \mathrm{~m}$ \\
\hline
\end{tabular}

$\mathrm{k}=1,000, \mathrm{~m}=1,000,000$

With data given in Table 3, three DEA models were proposed, firstly with two criteria: price and delivery and with price and quality and secondly, considering all three criteria.

Taking one modeling criteria at a time evaluation of the performance of suppliers is being done. Price and delivery analysis by applying DEA is shown in Table 4 .

Table 4. DEA analysis considering price and delivery

\begin{tabular}{|c|c|c|c|c|}
\hline Vendor & $\begin{array}{l}\text { Farrell } \\
\text { Efficiency }\end{array}$ & Slack Values & $\begin{array}{l}\text { Reference } \\
\text { Weights }\end{array}$ & Point of Efficiency \\
\hline 1 & 0.9505 & $\begin{array}{l}\text { Price - } 0 \\
\text { Delivery - } 0\end{array}$ & $\begin{array}{l}\mathrm{V} 2-0.7075 \\
\mathrm{~V} 4-0.2925\end{array}$ & $\begin{array}{l}\text { Price }-0.1939 \\
\text { Delivery }-4.953\end{array}$ \\
\hline 2 & 1.0 & $\begin{array}{l}\text { Price - } 0 \\
\text { Delivery - } 0\end{array}$ & $\mathrm{~V} 2-1.0$ & $\begin{array}{l}\text { Price }-0.1881 \\
\text { Delivery }-7.0\end{array}$ \\
\hline 3 & 1.0 & $\begin{array}{l}\text { Price }-0.0123 \\
\text { Delivery - } 0 \\
\end{array}$ & $\mathrm{~V} 4-1.0$ & $\begin{array}{l}\text { Price }-0.2081 \\
\text { Delivery }-0.0 \\
\end{array}$ \\
\hline 4 & 1.0 & $\begin{array}{l}\text { Price }-0 \\
\text { Delivery - } 0 \\
\end{array}$ & $\mathrm{~V} 4-1.0$ & $\begin{array}{l}\text { Price }-0.2081 \\
\text { Delivery }-0.0 \\
\end{array}$ \\
\hline 5 & 0.9403 & $\begin{array}{l}\text { Price - } 0 \\
\text { Delivery - } 0\end{array}$ & $\begin{array}{l}\text { V2 }-0.4047 \\
\text { V4 }-0.5953\end{array}$ & $\begin{array}{l}\text { Price }-0.2000 \\
\text { Delivery }-2.833\end{array}$ \\
\hline 6 & 0.9400 & $\begin{array}{l}\text { Price - } 0 \\
\text { Delivery - } 0\end{array}$ & $\begin{array}{l}\text { V2 }-0.5380 \\
\text { V4 }-0.4620\end{array}$ & $\begin{array}{l}\text { Price }-0.1973 \\
\text { Delivery }-3.7\end{array}$ \\
\hline
\end{tabular}

Calculation of point of efficiency is done by taking data from Table 3 of the vendor selected and then multiplying with its reference weights. Efficiency of individual suppliers is being calculated using reference weights. The efficiency points being calculated are the major evaluation points for supplier negotiation. For example, for becoming DEA efficient vendor 6 needs to reduce price factor by $\$ 0.0123$ and delivery delay which is calculated by late deliveries by $0.3 \%$. Similarly other vendors can be evaluated and vendors also can increase their efficiency by checking their performance through analysis of different criteria. After analyzing through price and delivery, next analysis is done through price and quality as shown in Table 5. In this model efficiency is calculated considering price and quality as major evaluating criteria. For example, for good and acceptable performance, vendor 1 needs price reduction of $\$ 0.0077$ per unit, and its percentage rejection from 0.4 to 0.8 . Combination of all the three criteria for DEA analysis: price, quality and delivery is shown in Table 6. In the third model, evaluation of vendors is done on the basis of price, quality and delivery according to vendor reference weights. According to this analysis, vendors 2, 3 and 4 are DEA efficient. In this analysis, the model output can evaluate and set different negotiation points for vendors as done in above two models 
considering two criteria. For example, Vendor 6 can be DEA efficient if it reduces its price by 0.0108 per unit, late deliveries reduction of 0.21 per cent, and reduction in rejected units by 0.07 per cent.

Table 5. DEA analysis considering price and quality

\begin{tabular}{|l|l|l|l|l|}
\hline Vendor & Farrell Efficiency & Slack Values & $\begin{array}{l}\text { Reference } \\
\text { Weights }\end{array}$ & Point of Efficiency \\
\hline 1 & 0.9607 & $\begin{array}{l}\text { Price }-0 \\
\text { Quality-0.2904 }\end{array}$ & V2 -1.0 & $\begin{array}{l}\text { Price }-0.1881 \\
\text { Quality }-0.8\end{array}$ \\
\hline 2 & 1.0 & $\begin{array}{l}\text { Price }-0 \\
\text { Quality }-0\end{array}$ & $\begin{array}{l}\text { V2 }-1.0 \\
\text { Price }-0.1881 \\
\text { Quality }-0.8\end{array}$ \\
\hline 3 & 1.0 & $\begin{array}{l}\text { Price }-0 \\
\text { Quality }-0\end{array}$ & V3 -1.0 & $\begin{array}{l}\text { Price }-0.2204 \\
\text { Quality }-0.0\end{array}$ \\
\hline 4 & 0.9034 & $\begin{array}{l}\text { Price }-0 \\
\text { Quality-0.5229 }\end{array}$ & V2 -1.0 & $\begin{array}{l}\text { Price }-0.1881 \\
\text { Quality }-0.8\end{array}$ \\
\hline 5 & 0.8881 & $\begin{array}{l}\text { Price }-0 \\
\text { Quality-0.5403 }\end{array}$ & V2 -1.0 & $\begin{array}{l}\text { Price }-0.1881 \\
\text { Quality }-0.8\end{array}$ \\
\hline 6 & 0.8974 & $\begin{array}{l}\text { Price }-0 \\
\text { Quality-0.2307 }\end{array}$ & V2 -1.0 & $\begin{array}{l}\text { Price }-0.1881 \\
\text { Quality }-0.8\end{array}$ \\
\hline
\end{tabular}

Table 6 DEA analysis considering price, quality and delivery

\begin{tabular}{|c|c|c|c|c|}
\hline Vendor & Farrell Efficiency & Slack Values & Reference Weights & Point of Efficiency \\
\hline 1 & 0.9905 & $\begin{array}{l}\text { Price }-0 \\
\text { Delivery }-0 \\
\text { Quality }-0.007\end{array}$ & $\begin{array}{l}\text { V2 }-0.7075 \\
\text { V4 }-0.2925\end{array}$ & $\begin{array}{l}\text { Price }-0.1939 \\
\text { Delivery }-4.953 \\
\text { Quality }-1.180\end{array}$ \\
\hline 2 & 1.0 & $\begin{array}{l}\text { Price }-0 \\
\text { Delivery }-0 \\
\text { Quality }-0\end{array}$ & $\mathrm{~V} 2-1.0$ & $\begin{array}{l}\text { Price }-0.1881 \\
\text { Delivery }-7.0 \\
\text { Quality }-0.8\end{array}$ \\
\hline 3 & 1.0 & $\begin{array}{l}\text { Price }-0 \\
\text { Delivery }-0 \\
\text { Quality }-0\end{array}$ & $\mathrm{~V} 3-1.0$ & $\begin{array}{l}\text { Price }-0.2204 \\
\text { Delivery }-0.0 \\
\text { Quality }-0.0\end{array}$ \\
\hline 4 & 1.0 & $\begin{array}{l}\text { Price }-0 \\
\text { Delivery }-0 \\
\text { Quality }-0\end{array}$ & $\mathrm{~V} 4-1.0$ & $\begin{array}{l}\text { Price }-0.2081 \\
\text { Delivery }-0.0 \\
\text { Quality }-2.1 \\
\end{array}$ \\
\hline 5 & 0.9443 & $\begin{array}{l}\text { Price }-0 \\
\text { Delivery }-0 \\
\text { Quality }-0.598\end{array}$ & $\begin{array}{l}\mathrm{V} 2-0.4047 \\
\mathrm{~V} 4-0.5953\end{array}$ & $\begin{array}{l}\text { Price }-0.2000 \\
\text { Delivery }-2.833 \\
\text { Quality }-1.574\end{array}$ \\
\hline 6 & 0.9483 & $\begin{array}{l}\text { Price }-0 \\
\text { Delivery }-0 \\
\text { Quality }-0\end{array}$ & $\begin{array}{l}\mathrm{V} 2-0.5419 \\
\mathrm{~V} 3-0.1226 \\
\mathrm{~V} 4-0.3355\end{array}$ & $\begin{array}{l}\text { Price }-0.1988 \\
\text { Delivery }-3.3793 \\
\text { Quality }-1.138\end{array}$ \\
\hline
\end{tabular}

\section{Conclusions}

In this paper, both the examples are based on application of DEA method of supplier selection and evaluation. In the first example, the vendor performance data is used by the firm for selection of vendors after calculating their efficiency point on the basis of six inputs and five outputs. With an extended approach the 
company of second example selects vendor on the basis of three parameters: price, quality and delivery. The three models used in this example also present negotiation points which can be beneficial for both the firm and supplier for the improvement of their efficiency and performance. Thus, it can be seen that DEA methodology can be applied depending upon the firm's requirement.

\section{References}

[1] Charnes A., Cooper W. W., and Rhodes E. Measuring the efficiency of decision making units. European Journal of Operational Research, 1978, 2(6), 429-444.

[2] Banker R. D., Charnes A. and Cooper W.W. Some models for estimating technical and scale inefficiencies in data envelopment analysis. Management Science (INFORMS), 1984, 30(9), 1078-1092.

[3] Banker R. D., and Moorey R.C. Efficiency analysis for exogenously fixed inputs and outputs. Operations Research (INFORMS), 1985, 34(4), 513-521.

[4] Boussofiane A., Dyson R.G., and Thanassoulis E. Applied data envelopment analysis. European Journal of Operational Research, 1991, 52(1), 1-15.

[5] Weber C.A. A data envelopment analysis approach to measuring vendor performance. Supply Chain Management: An International Journal, 1996, 1(1), 28-30.

[6] Braglia, M. and Petroni, A. A quality assurance-oriented methodology for handling trade-offs in supplier selection. International Journal of Physical Distribution and Logistics Management, 2000, 30(2), 96-111.

[7] Baker R.C. and Talluri S. A closer look at the use of DEA for technology selection. Computers and Industrial Engineering, 1997, 32(1), 101-108.

[8] Liu J., Ding F.Y., and Lall V. Using data envelopment analysis to compare suppliers for supplier selection and performance improvement. Supply Chain Management: An International Journal, 2000, 5(3), 143-150.

[9] Forker L.B., and Mendez D. An analytical method for benchmarking best peer suppliers. International Journal of Operations and Production Management, 2001, 21(1/2), 195-209.

[10] Narasimhan R., Talluri S., and Mendez D. Supplier evaluation and rationalization via data envelopment analysis: An empirical examination. Journal of Supply Chain Management, 2001, 37(3), 28-37.

[11] Talluri S., and Baker R.C. A multi-phase mathematical programming approach for effective supply chain design. European Journal of Operational Research, 2002, 41 (3), 544-558.

[12] Talluri S., and Sarkis J. A model for performance monitoring of suppliers. International Journal of Production Research, 2002, 40 (16), 4257-4269.

[13] Talluri S., and Narasimhan R. A methodology for strategic sourcing. European Journal of Operational Research, 2004, 154 (1), 236-250.

[14] Garfamy R.M. A data envelopment analysis approach based on total cost of ownership for supplier selection. Journal of Enterprise Information Management, 2006, 19 (6), 662-678.

[15] Ross A., Buffa F.P., Dröge C., and Carrington D. Supplier evaluation in a dyadic relationship: An action research approach. Journal of Business Logistics, 2006, 27 (2), 75-102.

[16] Saen R.F. A decision model for selecting technology suppliers in the presence of nondiscretionary factors. Applied Mathematics and Computation, 2006, 181 (2), 1609-1615.

[17] Seydel J. Data envelopment analysis for decision support. Industrial Management and Data Systems, 2006, 106 (1), 81-95.

[18] Talluri S., Narasimhan R., and Nair A. Vendor performance with supply risk: A chance-constrained DEA approach. International Journal of Production Economics, 2006, 100 (2), 212-222.

[19] Wu T., Shunk D., Blackhurst J., and Appalla R. AIDEA: A methodology for supplier evaluation and selection in a supplier-based manufacturing environment. International Journal of Manufacturing Technology and Management, 2007, 11 (2), 174-192.

[20] Kao C. Ranking Alternatives in Multiple Criteria Decision Analysis Based on a Common-Weight DEA. 
Proc of International Conference on Industrial Engineering and Operations Management. Islamic University of Technology, Dhaka, Bangladesh, 2010.

[21] Mondal S., and Chakraborty S. Flexible Manufacturing System Selection using Data Envelopment Analysis. Proc. of $3^{\text {rd }}$ International Conference on Advances in Mechanical Engineering S.V. National Institute of Technology, Surat, 2010, 852-856.

\section{Authors' Profiles}

Manjari Sahai is a SMB Manager at Denave India Pvt. Ltd, Noida, India. Prior to joining Deneve India, She was worked with HCL Infosystems Ltd. She did her MBA (IT) from Indian Institute of Information Technology Allahabad and B.Tech (Electronics Engineering) from Uttar Pradesh Technical University, India. Her areas of expertise include business development, partner management, IT risk management and business continuity planning.

Prince Agarwal is an assistant manager at HCL Technologies. He did his MBA (IT) from Indian Institute of Information Technology Allahabad and B.Tech (Information Technology) from Uttar Pradesh Technical University, India. He received Institute gold medal from IIIT Allahabad for the highest performance during his MBA (IT). His areas of interest include IT service management, business analytics, project management, transition management and logistics.

Vaibhav Mishra is pursuing $\mathrm{PhD}$ from Indian Institute of Information Technology Allahabad. He did his MBA (IT) from Indian Institute of Information Technology Allahabad and B.Tech (Computer Science and Engineering) from Uttar Pradesh Technical University, India. His areas of interest include Internet banking, IT service management, supply chain management, quality management and six sigma.

Monark Bag is an Assistant Professor of Production and Operations management area at Institute of Rural Management Anand (IRMA). Prior to joining IRMA, he was a faculty member at IMT Ghaziabad and Indian Institute of Information Technology Allahabad. He holds a B.Tech (Computer Science and Engineering), MBA (Information Technology Management) and PhD (Engineering). He was received "UGC Meritorious Fellowship" for his doctoral research entitled "An Expert System for Control Chart Pattern Recognition." His research interest includes expert system, control chart pattern recognition, quality control, optimization techniques and intrusion detection systems. He has published many papers in reputed journals, conferences and book chapters. He is a regular reviewer of various reputed international journals like Computers and Industrial Engineering (Elsevier), European Journal of Operational Research (Elsevier), Neurocomputing (Elsevier), Decision Science (Wiley), Journal of the Operational Research Society UK (Palgrave Macmillan), International Journal of Rural Management (Sage) etc.

Vrijendra Singh is an Assistant Professor at Indian Institute of Information Technology, Allahabad. Prior to joining IIITA, he was a senior project associate at Indian Institute of Technology, Kanpur. He holds PhD in Computer Science (Independent Component Analysis and Blind Source Separation applications to Signal Processing and Artificial Neural Networks). He is highly engaged in teaching and research. His research interest includes information security and forensics, artificial neural networks, machine learning, computational neuroscience, enterprise resource planning, data mining and digital signal processing. He has published many papers in reputed journals, conferences and book chapters. 